\title{
Effects of the working vacuum level on mechanical milking of buffalo
}

\author{
M. Caria, ${ }^{1}$ L. Murgia, and A. Pazzona \\ Dipartimento di Ingegneria del Territorio, Università degli Studi di Sassari, 07100 Sassari, Italy
}

\begin{abstract}
Mechanized milking has become widely used for buffalos in Italy in recent years, thus improving the management and the productivity of farms. The apparent similarities between buffalo and cattle have often resulted in applying the same milking systems and techniques currently used for dairy cows. Considering the effect of mechanical milking on animal health, productivity, and welfare in intensive livestock farming, this study compares the effects of milking at low vacuum $(36 \mathrm{kPa})$ and medium vacuum $(42 \mathrm{kPa})$ on milk emission characteristics and milking system performance. Individual milk flow curves were registered to analyze milk yield, average flow rate, and milking time, and milking operations were recorded to evaluate the system performances. When using $36 \mathrm{kPa}$ vacuum, a significant increase in milking time and in the lag time before milk ejection occurred, as well as a decrease in average flow rate and residual milk. However, the vacuum level did not influence both milk yield and milk ejection time. As a consequence of decreasing the vacuum level to $36 \mathrm{kPa}$, the milking system throughput was decreased at most by 5 buffalo/h.
\end{abstract}

Key words: animal welfare, buffalo, milking, working vacuum

\section{INTRODUCTION}

In recent years, a marked increase in dairy buffalo farming in Italy has taken place. There are now some 269,000 head of buffalo in Italy (ISTAT, 2008), and they are mainly found in the regions of Campania, Puglia, and Lazio. Mechanized milking is today largely diffused in buffalo farms, because it is the principal way of increasing work productivity and improving milk quality. Because cows and buffalo are apparently similar species, the experience and technology used for dairy cattle are usually employed also for buffalo, but it should be considered that both the anatomy and physiology of the 2 species are different. The udder

Received February 3, 2010.

Accepted January 5, 2011.

${ }^{1}$ Corresponding author: mariac@uniss.it cistern of buffalo is absent or has a very small volume and, therefore, little or no cisternal milk is available. Considering that buffalo teats are, on average, longer than in cows (Sastry et al., 1988), the effective length of the liner should be accurately chosen because the use of teat cups that are too short can alter the effect of the massage phase of the pulsation cycle. Buffalo are sensitive to changes in the milking parlor (Pathak, 1992), and are considered to be slow and hard milkers (Sastry et al., 1988) because of their slow milk ejection reflex and their sphincter muscle around the streak canal is thicker than in cattle (Ståhl Högberg and Lind, 2003).

For these reasons the working vacuum applied to buffalo is generally higher than the level used in cows so as to shorten the milking time (Table 1). In a recent field survey carried out in 189 installations for buffalo milking in Italy, the working vacuum levels varied from 40 to $53 \mathrm{kPa}$ (Figure 1). The most frequent values (45\%) ranged between 44 and $46 \mathrm{kPa}$, whereas only $4 \%$ of the installations were set at $\geq 50 \mathrm{kPa}$. A positive relationship between increasing working vacuum and the milk SCC has been found in buffalo (Badran, 1992; Pazzona and Murgia, 1992), which confirms preceding works on cows where raising the vacuum from 33 to over $50 \mathrm{kPa}$ had a negative effect on teat condition (Langlois et al., 1980) and increased mastitis incidence (Galton and Mahle, 1980; Langlois et al., 1980; Østeras and Lund, 1988). By contrast, increase in milking time and increased frequency of the teat cups falling off are the principal negative factors caused by lowering the milking vacuum level (Spencer and Rogers, 1991).

Because little or no cisternal milk is available in buffalos, in the early stage of milking, the animals are often exposed to a long period of vacuum without any ejection of milk. The use of high-working vacuums combined with the absence of milk can cause irritation in the delicate mammary tissues and, thus, stress the animals (Bruckmaier and Blum, 1996). Moreover buffalo are sensitive to the environment and the application of wrong milking technique or a change in milking routines can inhibit milk let-down, thus affecting negatively the milk production (Ståhl Högberg and Lind, 2003).

To deepen the knowledge on the milking dynamics of buffalo and define milking techniques that meet their physiological needs, a study was performed to verify 


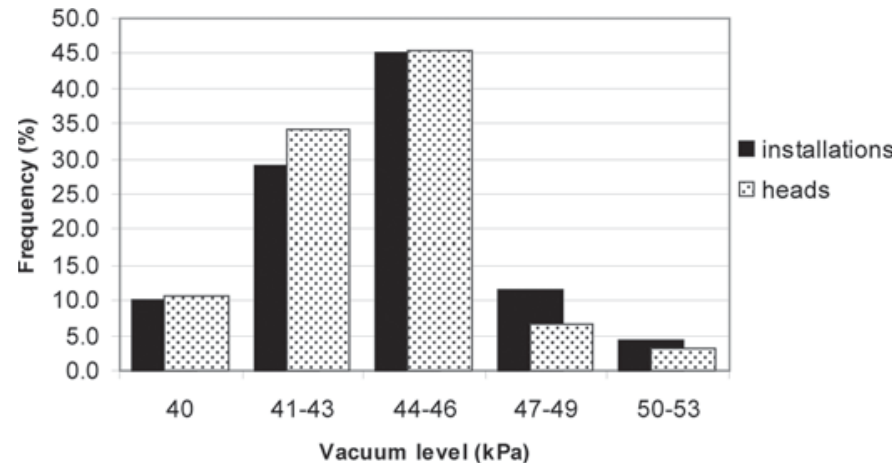

Figure 1. Frequency of vacuum level used for buffalo milking in Italy (189 installations, 21,740 heads). Data were based on field tests of Assaociazione Italiana Allevatori (AIA) in 2009 (S. Grande, AIA, Rome, Italy, personal communication).

the possibility of lowering the level of milking vacuum. Considering that Aliev (1969) reported that a vacuum pressure of over $30 \mathrm{kPa}$ is necessary to relax the teat sphincter in buffalo, we compared what effects using a low vacuum $(36 \mathrm{kPa})$, rather than a medium vacuum (42 kPa), had on the milk flow curve, the throughput of the milking system, and the operator performance.

\section{MATERIALS AND METHODS}

This work was carried out on a Mediterranean breed buffalo farm located in Latina, Italy. Four hundred and fifty milking buffalo, in different parity and stage of lactation, were used in the experiment. The milking system was a $2 \times 28$ parallel parlor with a low-level milking system equipped with a light-weight $(1.80 \mathrm{~kg})$ cluster (Harmony Plus, DeLaval, Tumba, Sweden), automatic cluster removers, and electronic herd management system (Alpro system, DeLaval). The cluster was equipped with conic rubber liners (length $=128$ $\mathrm{mm}$, diameter of mouthpiece lip $=20 \mathrm{~mm}$, thickness $=2.3 \mathrm{~mm}$ ) classified by the manufacturer as soft liner (softness rating 1) according to the touch point pressure differential measurement. The claw had a volume of $450 \mathrm{~mL}$, the diameter of the long milk tube was 16 $\mathrm{mm}$, and that of the short milk tube was $12.5 \mathrm{~mm}$. The pulsator rate was 60 cycles $/ \mathrm{min}$ and the pulsator ratio was $65 \%$. The working vacuum was tested for values of $42 \mathrm{kPa}$ and $36 \mathrm{kPa}$. Milk flow curves were recorded at $42 \mathrm{kPa}$ and, after $3 \mathrm{wk}$ of adaption to progressively lower vacuum levels, at $36 \mathrm{kPa}$, from all of the animals in lactation. Milking took place at intervals of $9 \mathrm{~h}$ (daytime) and $15 \mathrm{~h}$ (overnight).

The milking routine involved the attachment of the milking unit, without any preparation of the udder either by pre-stimulation or pre-dipping, and the manual removal of the teat cups without mechanical or manual stripping. During milking the animals were not given any concentrates.

Milk flow curves (48 curves/milking) were recorded at random during evening milking for $4 \mathrm{~d}$ at $36 \mathrm{kPa}$ and $6 \mathrm{~d}$ at $42 \mathrm{kPa}$, using 6 electronic mobile milk flow meters (LactoCorder, WMB, Balgach, Switzerland; Bava et al., 2007; Bava and Zucali, 2007; Borghese et al., 2007).

The variables measured per each milking were milk yield (MY; kg/head per milking), the total milk yield from the beginning to the end of the measurement; milking time (MT; min), the time from attaching to removing the teat cups; lag time (LT) before milk ejection (min), the time from the beginning of measurement until a $0.50 \mathrm{~kg} / \mathrm{min}$ threshold in the milk flow was reached; milk ejection time (MET; min), the time from milk flow rate $\geq 0.50 \mathrm{~kg} / \mathrm{min}$ until milk flow decreased below $0.20 \mathrm{~kg} / \mathrm{min}$; average milk flow rate $(\mathrm{kg} / \mathrm{min})$, the average main milk yield per minute during milk ejection time; effective milking time (EMT; min), the time between attaching the teat cup and reaching the value of $0.20 \mathrm{~kg} / \mathrm{min}$ at the end of milking; and residual milk (RM; kg), the quantity of milk extracted in the time between the flow decreasing to less than $0.20 \mathrm{~kg} /$ min and removal of the milking unit.

Statistical analysis was carried out by comparing the milk flow curves at 36 and $42 \mathrm{kPa}$, using a MannWhitney U test from the SPSS (ver. 15.0, SPSS, Inc., Chicago, IL).

Table 1. Different levels of working vacuum and the frequency and ratio of pulsations used when milking buffalo in different parts of the world (from Thomas, 2004, rielab.)

\begin{tabular}{llccc}
\hline $\begin{array}{l}\text { Authors and } \\
\text { year of publication }\end{array}$ & Country & $\begin{array}{c}\text { Vacuum } \\
(\mathrm{kPa})\end{array}$ & $\begin{array}{c}\text { Pulsator } \\
\text { frequency } \\
\text { (cycles/min) }\end{array}$ & $\begin{array}{c}\text { Pulsator } \\
\text { ratio (\%) }\end{array}$ \\
\hline Thomas and Anantkrishnan (1949) & India & 46 & 50 & - \\
Marathe and Whittlestone (1958) & India & 68 & 40 & 50 \\
Aliev (1970) & Azerbaijan & 56 & 60 & 50 \\
Alim (1977) & Egypt & 51 & 60 & 60 \\
Pazzona (1989b) & Italy & 45 & 60 & 65 \\
Badran (1992) & Egypt & 56 & 65 & 65 \\
Lind et al. (1997) & India & 56 & 70 & \\
Thomas et al. (2005a) & India & 50 & 70 & \\
\hline
\end{tabular}


Table 2. Mean milk production, milk flow rate, and milking times per buffalo and range of milk production, milk flow rate, and milking times for 2 vacuum levels

\begin{tabular}{|c|c|c|c|c|c|c|c|}
\hline Variable & \multicolumn{3}{|c|}{$36-\mathrm{kPa}$ vacuum } & \multicolumn{3}{|c|}{$42-\mathrm{kPa}$ vacuum } & $P$-value \\
\hline Milk yield (kg/milking) & $3.6 \pm 0.15$ & 1.0 & 8.5 & $4.1 \pm 0.14$ & 1.1 & 11.5 & 0.109 \\
\hline Milking time $(\min )$ & $12.90 \pm 0.32$ & 5.46 & 23.85 & $11.39 \pm 0.20$ & 5.69 & 22.03 & 0.000 \\
\hline Lag time before milk ejection (min) & $2.82 \pm 0.27$ & 0.19 & 12.46 & $2.39 \pm 0.17$ & 0.09 & 11.57 & 0.049 \\
\hline Effective milking time (min) & $8.13 \pm 0.34$ & 3.45 & 19.04 & $7.36 \pm 0.24$ & 1.77 & 21.42 & 0.048 \\
\hline Residual milk (kg) & $0.068 \pm 0.01$ & 0.01 & 0.45 & $0.130 \pm 0.01$ & 0.008 & 0.472 & 0.000 \\
\hline
\end{tabular}

During the experiment, the operator work time for each buffalo was measured, including access time and idle/waiting times. These data allowed us to calculate the throughput of the milking system and the operator performance at vacuums of 36 and $42 \mathrm{kPa}$.

\section{RESULTS AND DISCUSSION}

\section{Milk Flow Curves}

The results for each variable at the 2 vacuum levels are shown in Table 2. Comparison of the MY was not statistically different at the 2 vacuum levels. The average values obtained during our tests, $3.6 \mathrm{~kg} /$ milking at $36 \mathrm{kPa}$ and $4.1 \mathrm{~kg} /$ milking at $42 \mathrm{kPa}$, mirror the data recorded in previous studies (Bava and Zucali, 2007; Borghese et al., 2007). The high variability in individual milk production was related to the presence of animals at different stages of lactation.

The operator's choice to not use automatic cluster removers (ACR) strongly influenced the milking unit in regard to time, as shown by the extension of milking curves at a milk flow $\leq 0.20 \mathrm{~kg} / \mathrm{min}$, both at $36 \mathrm{kPa}$ (4.77 min) and $42 \mathrm{kPa}$ (4.03 min; Figure 2). The average MT was 12.90 min at $36 \mathrm{kPa}$, decreasing to 11.39 min at $42 \mathrm{kPa}$, with a highly significant difference of $1.51 \mathrm{~min}(P<0.001)$. These values confirm that, as reported for dairy cows (Reinemann et al., 2001), the milking time tends to increase as the working vacuum diminishes.

The EMT, calculated from the teat cup attachment to the point where the milk flow rate falls under 0.20 $\mathrm{kg} / \mathrm{min}$, considers the milking time as if automatic cluster remover were used. When a vacuum of $36 \mathrm{kPa}$ was used, the EMT increased, on average, by $0.77 \mathrm{~min}(P$ $=0.048)$, even though the longest value was recorded at $42 \mathrm{kPa}$ (21.42 $\mathrm{min})$. The MT was 35 to $37 \%$ higher than the EMT, which indicates that the vacuum was applied to the udder even when the milk flow was low or absent, with obvious effects on the health of the mammary tissues (Hillerton et al., 2002).
By separating out LT and MET from the EMT, one can identify which of the 2 phases was most influenced by the vacuum level. Table 2 shows that MET averaged about 5 min and did not vary at different vacuums, showing that a level of $36 \mathrm{kPa}$ is sufficient to guarantee the opening of the teat canal. The vacuum decrease has the advantage of decreasing the risk of negative effects on udder health and milk quality, as shown by previous studies both on buffalo (Pazzona and Murgia, 1992) and other dairy species (Le Du, 1983, 1985; Hamann, 1990; Pazzona and Murgia, 1992; Pazzona and Murgia, 1993; Rasmussen, 1993; Fernandez et al., 1999; Sinapis and Vlachos, 1999; Rasmussen and Madsen., 2000; Mein et al., 2003).

The rise in EMT seems to be more connected to the initial phase of milking (i.e., the time waiting for the real milk flow to begin). In fact, LT varied significantly, increasing by $0.4 \mathrm{~min}$ when the lower vacuum level was used $(P=0.049)$. The average values obtained, 2.82 and $2.39 \mathrm{~min}$, respectively, at 36 and $42 \mathrm{kPa}$ (Figure 3 ), were higher than those found in other studies, both with preliminary massage (Pazzona, 1989a) and without preparation of the udder (Bava and Zucali., 2007). This increase in time could be related to the fact that no concentrates were given to the animals during milking (Thomas et al., 2005a).

The longer lag time before milk ejection can also be attributed to the anatomical characteristics of the mammary gland and teats of buffalo. The udder cistern is absent or has small volume and, therefore, little or no cisternal milk is available. This leads to no intramammary pressure in the cistern, which would otherwise help the milk flow (Ståhl Högberg and Lind, 2003). The teats are longer and narrower than those of cows and the sphincter muscle is of greater consistency (Thomas et al., 2004). These anatomical characteristics, on one hand, may decrease the incidence of mastitis when compared with cows (Uppal et al., 1994), but on the other hand, require a higher vacuum level to overcome the greater resistance of the teat sphincter. 


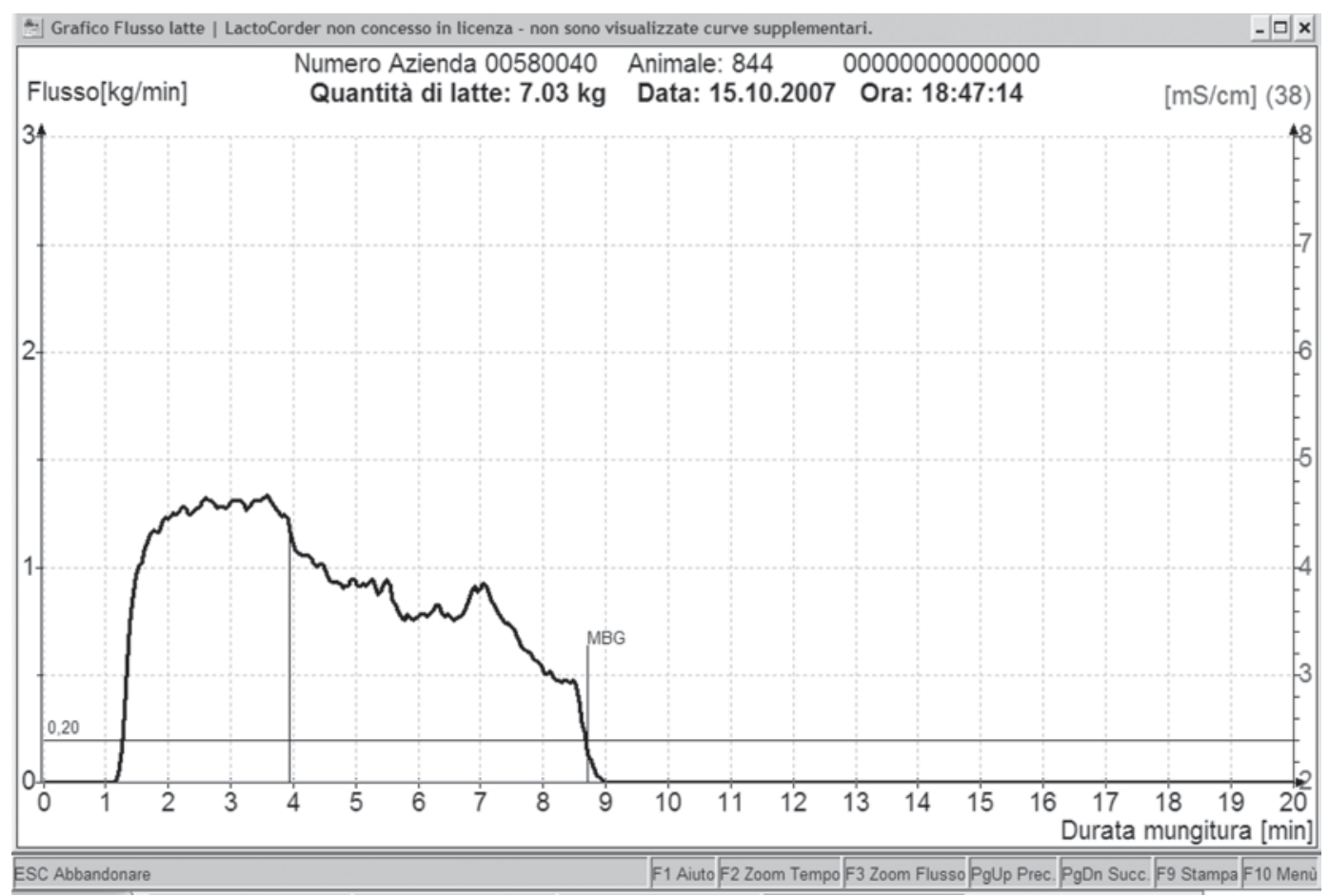

Figure 2. An example of a milk emission curve where the milking unit remained attached for about 11 min, even when milk flow was absent. MBG indicates the overmilking starting point (milk flow rate decline below $0.20 \mathrm{~kg} / \mathrm{min}$ )

As expected, the average milk flow rate during the MET increased significantly when the vacuum level was set at $42 \mathrm{kPa}$ instead of $36 \mathrm{kPa}(0.79$ vs. $0.69 \mathrm{~kg} / \mathrm{min}$, $P=0.007)$. Both values are markedly lower than those reported by Bava and Zucali (2007), corresponding to $0.91 \mathrm{~kg} / \mathrm{min}$ at $45 \mathrm{kPa}$. These results are due to the fact that the quantity of milk obtained in the ejection phase at the lower vacuum level is less than the one obtained at a vacuum level of $42 \mathrm{kPa}$. Because milk flow rate largely depends on the elasticity of the teat canal (Mein, 1992; Nickerson, 1992), and milk ejection begins when the resistance of the teat canal is overcome, increasing the working vacuum increases the peak flow rate.

The RM was significantly higher when using a vacuum level of $42 \mathrm{kPa}$ instead of $36 \mathrm{kPa}(P<0.001)$, as previously reported by other studies on dairy cows, where increased strip yield was associated with increased vacuum level (Hamann et al., 1993; Reinemann et al., 2001). With respect to MY, the percentage value of the RM fraction was just $1.9 \%$ at $36 \mathrm{kPa}$, whereas it increased to $3.2 \%$ at $42 \mathrm{kPa}$, in accordance with the values obtained by Borghese et al. (2007) at $45 \mathrm{kPa}$ operative vacuum. These results suggest that even though a lower vacuum prolongs the MT, the modest RM does not require eventual udder stripping, and, consequently, ACR could be used so as to improve the milking system performance.

\section{Milking Routine}

During the whole milking session, the duration of each phase of the routine was analyzed, to define the operator performance and the milking system throughput as a function of the individual milking time at the working vacuums of $36 \mathrm{kPa}$ and $42 \mathrm{kPa}$ (Table 3). Based on the analysis of the milking routine, a mathematical model has been developed to calculate the performances of the milking installation at the 2 values of working vacuum.

The milking routine of a milking session can be divided in 2 phases, $T_{1}$ and $T_{2}$, as follows: $T_{1}$ is the first phase of the routine, which includes the preliminary actions for preparing the udders $(P o)$ and attaching the clusters (Tag), to which is added the movement time among the stalls $\left(T_{C} \cdot N\right)$ :

$$
T_{1}=N(P o+T a g)+T_{C} \cdot N
$$

The optimal number of milkers $(M)$ is calculated on the basis of the relationship between time $T_{1}$, plus the idle/waiting time $(T r)$ of the milkers in this phase, and the average milking time per animal $(\mathrm{Tm})$. In this way, one ensures the presence of the operator at the end of milking of the first buffalo that has had the clusters attached: 
Table 3. Working times for each action in a rapid exit parallel milking parlor with automatic cluster remover

\begin{tabular}{lllc}
\hline & & Unit of & Working \\
Action & Symbol & measurement & time \\
\hline Cluster attachment & $T a g$ & s/buffalo & 9 \\
Parlor entry time & $T i$ & s/buffalo & 7 \\
Parlor exit time & $T u$ & s/buffalo & 4 \\
Movement time between 2 adjacent buffalo & $T_{C}$ & s/buffalo & 0.8 \\
Idle/waiting time & $T r$ & Percent of the & 9.4 \\
& & routine time & \\
\hline
\end{tabular}

$$
M=\frac{T_{1} \cdot(1+T r)}{T m}
$$

The second phase of the routine is $T_{2}$, where the postmilking operations, such as treatment of the udders $(P t)$, are carried out, as well as the manual detachment of the milking units $(T d g)$ :

$$
T_{2}=T_{C} \cdot N+N(T d g+P t) .
$$

The total milking time for the herd $(T t m)$ includes the duration of the 2 phases $T_{1}$ and $T_{2}$, the time spent moving the animals in and out of the milking parlor $(T i, T u)$, the idle/waiting time in each milking cycle, and the $\operatorname{Tr}$ of the milker, calculated as a percentage of the total milking time for the herd:

$$
T t m=\left\{\begin{array}{l}
\frac{N a}{N} \cdot\left[\begin{array}{l}
\frac{T_{1}}{M}+\left(T m-\frac{T_{1}}{M}\right)+\frac{T_{2}}{M}+(T m+T d g+P t) \\
-\left(T m-\frac{T_{1}}{M}+\frac{T_{2}}{M}\right) \\
+N a \cdot T i+N a \cdot T u
\end{array}\right]
\end{array}\right] \cdot(1+T r) .
$$

Simplifying the above equation we obtain

$$
T t m=\left[\frac{N a}{N} \cdot\left(\frac{T_{1}}{M}+T m+T d g+P t\right)+N a \cdot(T i+T u)\right] \cdot(1+T r),
$$

where $N a=$ number of milking animals, and the idle/ waiting time and $T_{2}$ are superimposed on the time $T m$

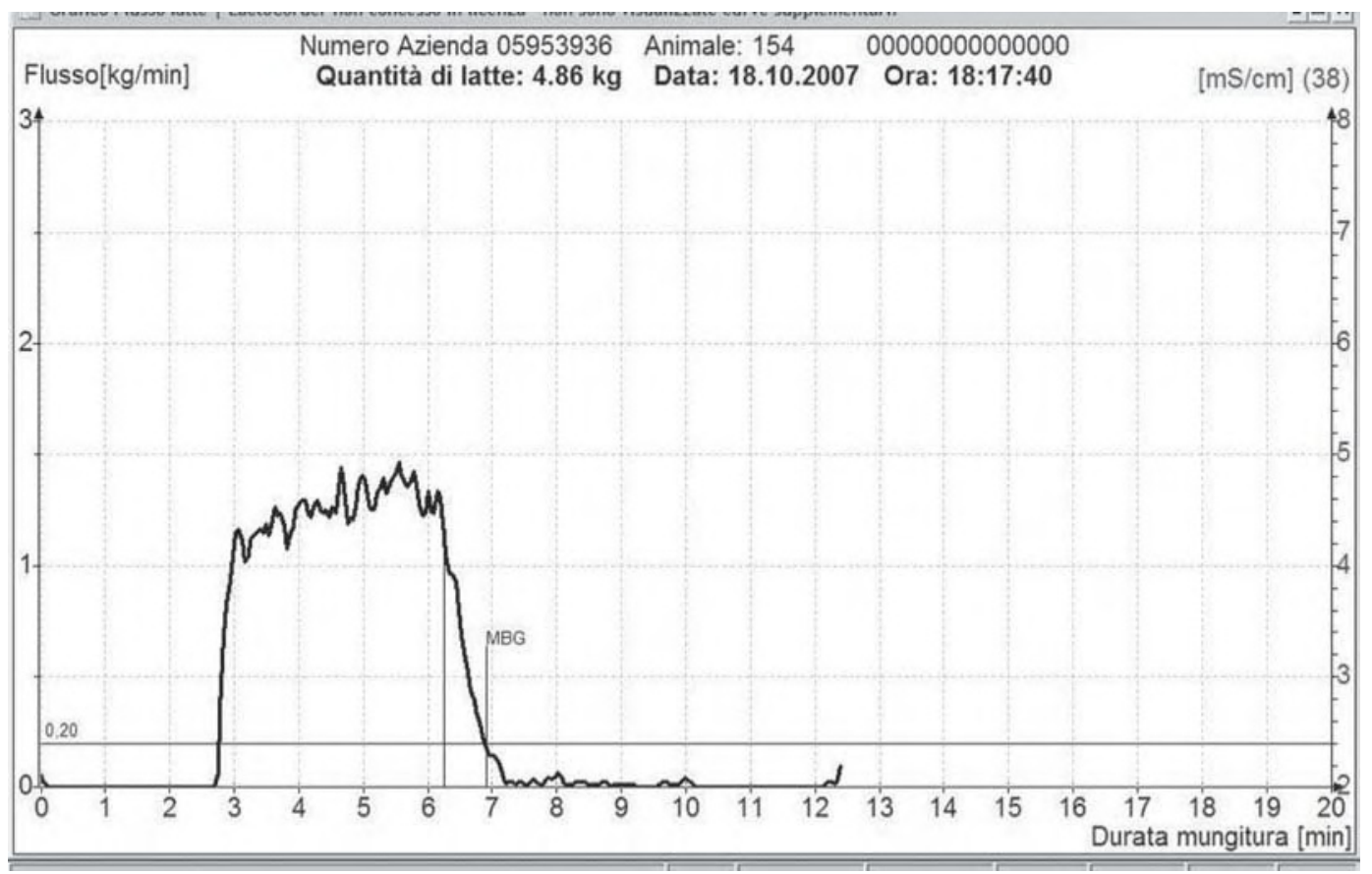

Figure 3. An example of an emission curve with a long lag time before milk ejection. Note that the milk ejection time is less than the time when milk flow was absent. MBG indicates the overmilking starting point (milk flow rate decline below $0.20 \mathrm{~kg} / \mathrm{min}$ ) 
Table 4. Throughput of milking system and operator performance at different vacuum levels as a function of the routine and the number of workers 1

\begin{tabular}{|c|c|c|c|c|c|c|c|}
\hline Item & $M$ & \multicolumn{3}{|c|}{$36-\mathrm{kPa}$ vacuum } & \multicolumn{3}{|c|}{$42-\mathrm{kPa}$ vacuum } \\
\hline Effective milking time & 2 & 8.13 & 134 & 67 & 7.36 & 139 & 69 \\
\hline
\end{tabular}

${ }^{1} M=$ optimal number of milkers; $T m=$ average milking time per animal; $C o=$ throughput of the milking system; $P=$ operator performance.

$+T d g+P t$ of the last buffalo to which the milking unit has been attached, and which, thus, do not have an effect on Ttm.

The throughput of the milking system $(\mathrm{Co})$ and the operator performance $(P)$ were calculated as

$$
\begin{gathered}
C o=\frac{N a}{T t m}(\text { buffalo } / h) \\
P=\frac{N a}{T t m \cdot M}(\text { buffalo } / \text { man hours }) .
\end{gathered}
$$

Referring to the $2 \times 28(28+28$ stalls $)$ milking system and to the results obtained from the milk curves, the model was applied to a milking routine without pre-stimulation or postmilking treatment, stripping of the udders, and the use of automatic cluster removers set at $0.20 \mathrm{~kg} / \mathrm{min}$. In this way, the calculations were based on the EMT, excluding the final part of milking because of the low volume of RM.

From [2], the optimal number of milkers results in 1.4 at $42 \mathrm{kPa}$ vacuum and 1.3 at $36 \mathrm{kPa}$; as a consequence, we have considered both milking with 1 and 2 operators. In the first case, because EMT was 8.13 min at $36 \mathrm{kPa}$ and $7.36 \mathrm{~min}$ at $42 \mathrm{kPa}$, the Ttm calculation resulted in $4.04 \mathrm{~h}$ and $3.92 \mathrm{~h}$ at the 2 vacuum levels, which correspond, respectively, to a Co of 111 buffalo/h and 115 buffalo/h (Table 4 ), with a difference of 3.4 buffalo/h.

Considering 2 milkers instead of one, Ttm decreases, because $T_{1}$ in [5] is divided by $M$. The Ttm calculation resulted in $3.25 \mathrm{~h}$ at $42 \mathrm{kPa}$ of vacuum and $3.36 \mathrm{~h}$ at 36 $\mathrm{kPa}$, corresponding to a $C o$ of 139 and 134 buffalo/h, respectively. In this case, the $P$ is 69 buffalo/man-hour, at a vacuum of $42 \mathrm{kPa}$ and 67 buffalo/man-hour at a vacuum of $36 \mathrm{kPa}$, with a difference of 2 buffalo/manhour. When the routine includes accessory actions, such as postmilking treatment, then this mainly affects the Ttm.

\section{CONCLUSIONS}

The results of our study show that milking dairy buffalo at low vacuum level slightly affect milking process performances, whereas it could have positive effects on the animal health. Decreasing the working vacuum did not influence significantly MY and the MET. These results clearly showed that even a vacuum of $36 \mathrm{kPa}$ is more than enough to guarantee that the teat canal opens. By contrast a significant increase in MT (1.1 min) was observed due to a longer LT and a prolonged time for the complete emptying of the udder. As suggested by Hamann et al. (1993), the duration of milking in cows seems to influence teat tissue reactions less than the high vacuum. In farms where the LT could be shortened by inducing milk let-down through pre-stimulation of the udders along with feeding concentrate in the parlor, the use of a low milking vacuum level might represent an appropriate choice, considering the advantages that it offers in terms of animal health and well-being. The efficiency of milking routine also was influenced by the working vacuum level. When decreased from 42 to $36 \mathrm{kPa}$, it slightly affected the throughput of the milking system and the operator performance, like in other dairy species (Pazzona et al., 2009). The Co was reduced by about $3.6 \%$, corresponding to about a 7-min increase in the time spent for the whole milking session, operating both with 1 and 2 milkers. This short time does not compromise the management of the milking and the farm labor organization, considering that the use of ACR strongly decreases the milking time. In reference to the optimal number of milkers, it is clear that with 1 operator, the labor cost is decreased, but the Ttm will be prolonged by about $40 \mathrm{~min}$ at both vacuum levels. In this case, the use of ACR is recommended to decrease the risk of animal overmilking. The final choice of the farmer will depend on farm management and economic factors, such as local labor cost.

\section{ACKNOWLEDGMENTS}

Gratitude is expressed to Carlo Boselli (Animal Prophylaxis Research Institute for Lazio and Toscana Regions, Italy) and Lorenzo Banchelli (zoonomist) for their support in farm data collection.

\section{REFERENCES}

Aliev, M. G. 1969. Physiology of milk ejection in buffaloes. Dairy Sci. Abstr. 31:677-680. 
Aliev, M. G. 1970. Physiology of machine milking of buffaloes. Dairy Science Abstr. 32:329-332.

Alim, K. A., A. Barbari, and A. Badran. 1977. Management trials on milking technique and concentrates feeding with local cattle and buffalo. World Rev. Anim. Prod. 13:27-32.

Badran, A. E. 1992. Effect of vacuum and pulsation rate on milking ability in Egyptian buffaloes. Buffalo J. 1:1-7.

Bava, L., A. Sandrucci, A. Tamburini, and M. Zucali. 2007. Milk flow traits of buffalo cows in intensive farming system. Ital. J. Anim. Sci. 6(Suppl. 1):500-502.

Bava, L., and M. Zucali. 2007. Una buona mungitura con una giusta routine. Informatore Zootecnico 18:156-169.

Borghese, A., M. Mazzi, R. Rosati, and C. Boselli. 2007. Milk flow pictures in Mediterranean Italian buffaloes, through Lactocorder instrument. Pages 60-63 in Proc. International Symposium on Advances in Milking, Cork, Ireland.

Bruckmaier, R. M., and J. W. Blum. 1996. Simultaneous recording of oxytocin release, milk ejection and milk flow during milking of dairy cows with and without prestimulation. J. Dairy Res. 63:201-208.

Fernandez, N., J. R. Diaz, C. Peris, M. Rodriguez, M. P. Molina, and A. Torres. 1999. Machine milking parameters for the Manchega sheep breed. Pages 233-238 in Proc. Sixth International Symposium in Machine Milking of Small Ruminants, Athens, Greece. European Association for Animal Production (EAAP) Publication no. 95. Wageningen Academic Publishers, Wageningen, the Netherlands.

Galton, D. M., and D. E. Mahle. 1980. Effects of vacuum level and pulsation ratio on udder health. Proc. Annu. Mtg. Nat. Mastitis Council Inc. 19:39-43.

Hamann, J. 1990. Effect of machine milking on teat end condition with special emphasis on infection risk. World Review of Animal Production 25:9-12.

Hamann, J., G. A. Mein, and S. Wetzel. 1993. Teat tissue reactions to milking: Effects of vacuum level. J. Dairy Sci. 76:1040-1046.

Hillerton, J. E., J. W. Pankey, and P. Pankey. 2002. Effect of overmilking on teat condition. J. Dairy Res. 69:81-84.

ISTAT (Italian National Institute of Statistics). 2008. Accessed September 2008. http://agri.istat.it/excel/Dw92008.xls.

Langlois, B. E., J. C. Cox, R. W. Hemken, and J. Nicolai. 1980. Effect of milking vacuum on some indicators of bovine mastitis. J. Dairy Sci. 63(Suppl. 1):116-117.

Le Du, J. 1983. Comparaison d'un lactoduc en ligne haute et in ligne basse. Incidence sur la traite des brebis de races Lacaune et Manech. Ann. Zootech. 32:43-52.

Le Du, J. 1985. Paramètres de fonctionnement affectant l'efficacité des machines a traire pour brebis et chèvres. Pages 430-431 in 36ème Reunion Annuelle F.E.Z., Ed. Giahoudi Bros Publication, Thessalonique, Grèce.

Lind, O., K. Ranade, and C. S. Thomas. 1997. Experiences from machine milking of buffaloes. Pages 916-917 in Proc. 5th World Buffalo Congress, Caserta, Italy. A. Borghese, S. Failla, and V. L. Barile, ed.

Marathe, M. R., and W. G. Whittlestone. 1958. The machine milking characteristics of water buffaloes. Indian J. Dairy Sci. 11:59-66.

Mein, G. A. 1992. Action of the cluster during milking. Pages 97-140 in Machine Milking and Lactation. A. J. Bramley, F. H. Dodd, G. A. Mein, and J. A. Bramley, ed. Insight Books, Newbury, UK.

Mein, G. A., D. M. D. Williams, and D. J. Reinemann. 2003. Effects of milking on teat-end hyperkeratosis: 1. Mechanical forces applied by the teatcup liner and responses of the teat. Pages 114-123 in Natl. Mastitis Counc. Reg. Mtg. Proc., Fort Worth, TX. National Mastitis Council, Madison, WI.

Nickerson, S. C. 1992. Anatomy and physiology of the udder. Pages 37-68 in Machine Milking and Lactation. A. J. Bramley, F. H. Dodd, G. A. Mein, and J. A. Bramley, ed. Insight Books, Newbury, UK.

Østeras, O., and A. Lund. 1988. Epidemiological analyses of the associations between bovine udder health and milking machine and milking management. Prev. Vet. Med. 6:91-108.
Pathak, N. N. 1992. Behaviour and training of river buffaloes. Pages 223-231 in Buffalo Production. World Anim. Sci. Ser., chapter 6. N. M. Tulooh and J. H. G. Holmes, ed. Elsevier Scientific Publishing, Amsterdam, the Netherlands.

Pazzona, A. 1989a. Influenza del gruppo prendicapezzoli sulla mungitura meccanica delle bufale. Rivista di Ingegneria Agraria $4: 227-233$.

Pazzona, A. 1989b. The effect of the weight of the clusters and the shape of the teat-cup liners on the milking characteristics of the buffalo. J. Agric. Eng. Res. 43:175-181.

Pazzona, A.. M. Caria, and L. Murgia. 2009. Effects of a low vacuum level on vacuum stability and milking parlor performance for sheep. Trans. ASABE 52:247-252.

Pazzona, A., and L. Murgia. 1992. Effect of milking vacuum on leucocyte count in buffalo milk. Pages 691-694 in Proc. 24th International Conference on Agricultural Mechanization, Zaragoza, Spain.

Pazzona, A., and L. Murgia. 1993. Effetto del vuoto di mungitura e delle frequenze di pulsazione sulla carica leucocitaria del latte di pecora. L'Informatore Agrario 42:43-46.

Rasmussen, M. D. 1993. Influence of switch level of automatic cluster removers on milking performance and udder health. J. Dairy Res. 60:287-297.

Rasmussen, M. D., and N. P. Madsen. 2000. Effects of milkline vacuum, pulsator airline vacuum, and cluster weight on milk yield, teat condition, and udder health. J. Dairy Sci. 83:77-84.

Reinemann, D. J., M. A. Davis, D. Costa, and A. C. Rodriguez. 2001. Effects of milking vacuum on milking performance and teat condition. Proc. AABP-NMC International Symposium on Mastitis and Milk Quality, Vancouver, BC, Canada. Natl. Mastitis Counc., Verona, WI.

Sastry, N. S. R., S. S. Bhagat, and A. Bharadwaj. 1988. Aspects to be considered in milking management of buffaloes. Indian J. Anim. Prod. Manag. 4:378-393.

Sinapis, E., and I. Vlachos. 1999. Influence du niveau de vide de la machine a traire et des facteurs zootechniques sur le comptages de cellules somatiques chez les chevres locale grecque. Pages 513518 in Proc. Sixth International Symposium in Machine Milking of Small Ruminants, Athens, Greece. European Association for Animal Production (EAAP) Publication no. 95. Wageningen Academic Publishers, Wageningen, the Netherlands.

Spencer, S. B., and G. W. Rogers. 1991. Effect of vacuum and milking machine liners on liner slip. J. Dairy Sci. 74:429-432.

Ståhl Högberg, M., and O. Lind. 2003. Milking the buffalo. Buffalo milk production. Ari. Lic. Animal Husbandry, Department of Nutrition and Management, Sweden.

Thomas, C. S. 2004. Milking management of dairy buffaloes. PhD Thesis. Swedish Univ. of Agric. Sci.., Uppsala, Sweden.

Thomas, C. S., R. M. Bruckmaier, K. Östensson, and K. SvennerstenSjaunja. 2005a. Effect of different milking routines on milkingrelated release of the hormones oxytocin, prolactin and cortisol, and on milk yield and milking performance in Murrah buffaloes. J. Dairy Res. 72:10-18.

Thomas, C. S., J. Nordstrom, K. Svennersten-Sjaunja, and H. Wiktorsson. 2005b. Maintenance and milking behaviours of Murrah buffaloes during two feeding regimes. Appl. Anim. Behav. Sci. 91:261-276.

Thomas, C. S., K. Svennersten-Sjaunja, M. R. Bhosrekar, and R. M. Bruckmaier. 2004. Mammary cisternal size, cisternal milk and milk ejection in Murrah buffaloes. J. Dairy Res. 71:162-168.

Thomas, S. P., and C. P. Anantakrishnan. 1949. Investigations on machine milking. Indian J. Dairy Sci. 2:70-76.

Uppal, S. K., K. B. Singh, K. S. Roy, D. S. Nuriyal, and B. K. Bansal. 1994. Natural defence mechanism against mastitis: A comparative histomorphology of buffalo teat canal. Buffalo J. 2:125-131. 